\title{
Rural non-farm employment and rural diversity in Latin America
}

\author{
Martine Dirven
}

I

the 1990s, rural development specialists became increasingly interested in rural non-farm employment (RNFE) and the factors determining it. Ideas about the subject gradually made their way into the political debate and some development programmes. Location is one of the aspects mentioned in many studies as a factor influencing the characteristics of RNFE. Some others include scale, type, generated income and participating household members. This article looks at what has been written on the subject and suggests that location, and the various "distances" that go with it, are a vital determinant of RNFE.

Martine Dirven

Chief, Agricultural Development Unit, Division of Production, Productivity and Management,

ECLAC

- mdirven@eclac.cl 


\section{I}

\section{Introduction}

From a policy perspective, it is important to know whether all rural areas can have diversified economies, whether the rural poor are capable of optimizing the opportunities that rural non-farm employment (RNFE) may offer them or whether they need special policies to help them. Evidence shows that patterns of participation and the scope for responding to opportunities strongly differ among population groups depending on their gender, their age and, above all, their personal or household assets, the location of their residence and their access to public and private assets. An issue tackled in this article, but hitherto little studied, is the relation between location in the territory, and therefore "distances", and RNFE.

RNFE has been receiving increasing attention in Latin America since the 1990s. Various studies have examined how different assets (public and private) relate to it in different income groups and how, in turn, different rural non-farm occupations affect incomes. Several of these studies were published in a special issue of World Development (vol. 29, No. 3, September 2001) devoted to RNFE. We shall draw heavily on these in what follows.

The article is divided into seven sections. Section II that follows explains some of the definitions used in Latin America and in the rest of the text. Section III points to reasons for RNFE growth. Section IV gives an idea of the orders of magnitude of RNFE in Latin America. Section V is about RNFE and assets, private (such as land, education and the attributes of household members) and public (such as roads and electrification), but also location and the dynamism of local agriculture. Section VI is about RNFE and "distances". Lastly, section VII is about some conclusions for policy and further research issues.

\section{II}

\section{Some definitions}

There are several ways of looking at rural residents' non-agricultural employment, among which three stand out. One way generally centres on case studies of one of a household's members' occupations, taking the household as a unit of analysis. The emphasis is not necessarily on the principal activity of the household nor that of any of its members, but the specific activity

\footnotetext{
$\square$ A previous version of this article was presented at the symposium "The rural non-farm economy in the developing world and transition economies: an answer to rural poverty?", part of the Seventy-seventh Annual Conference of the Agricultural Economics Society of the United Kingdom (AES), 11 to 14 April 2003, Seale-Hayne, Newton Abbott, Devon. A shorter version was presented at the "Social Transformations" session of the international seminar "The rural world: transformations and perspectives in the light of the new rurality", Bogota, Colombia, 15-17 October 2003, under the title "Rural non-farm employment: the importance of 'distances". The author wishes to thank Steve Wiggins of the Overseas Development Institute as well as an anonymous reviewer for their useful comments.
}

that the author wants to analyse in more detail. ${ }^{1} \mathrm{~A}$ second way centres on the household's main activity or income source, often ascertained from the answers to household surveys and usually considering the answers of the household head as determining. A third way centres on the main activity of each individual, household surveys or population censuses being the main sources of information. It is this information that will be used in the analysis that follows, i.e., the primary employment in non-agricultural activities of residents of rural areas.

In Spanish, this was coined as "empleo rural no agrícola" or ERNA, that is "rural non-agricultural

\footnotetext{
${ }^{1}$ Several examples of such studies (the making of straw hats in Peru and jeans in Ecuador) were presented at the Third Latin American Symposium on agricultural systems research and extension, "New ways of fighting rural poverty and developing local capacities" (Nuevos enfoques para la superación de la pobreza rural y para el desarrollo de las capacidades locales), Lima, August 1998.
} 
employment". Thus, it does not include work which is off-farm but agricultural, whereas this may or may not be treated as part of the English concept of "rural nonfarm employment" (RNFE), depending on the author. For the sake of simplicity we shall use RNFE as the equivalent of ERNA, as has in fact been done by many authors and translators. In the rest of the text RNFE will have the definition Reardon, Berdegué and Escobar (2001, p. 396) give it: "By RNFE we mean employment of rural household members in the nonfarm sector... 'Nonfarm' means an activity outside agriculture... hence in manufactures and services. We follow standard national accounts definitions, wherein agriculture produces raw agrifood products with one of the production factors being natural resources (land, rivers/lakes/ocean, air); the process can involve 'growing' (cropping, aquiculture, livestock husbandry, woodlot production) or 'gathering' (hunting, fishing, forestry)."

Both acronyms, however, induce the erroneous idea that the activity takes place in a rural area. In fact, it concerns the individual who resides in an area defined as rural by the particular country's census and who carries out a non-agricultural activity, without indication of where this takes place. This has confused analysts and policy makers alike and kindled an enthusiasm for "rural revival" which is, at least partially, based on having the facts wrong.

An important factor when analysing RNFE-related issues in Latin America are the definitions used for "rural". There are five broad definitions of "rural" used in Latin American population censuses and therefore also in household surveys: those based on maximum population per locality (around 2,000 persons per locality in most countries); number of contiguous houses (Peru); legal definitions (Brazil, Ecuador, Guatemala, Uruguay); outside the municipal centre (cabecera municipal) (Colombia, Dominican Republic, El Salvador, Paraguay); and "non-urban characteristics" (Costa Rica and Haiti). Moreover, hardly any country uses exactly the same definition and several countries have changed definitions over the years.

A low population density and large physical (and other) distance(s) between settlements are characteristics of most rural areas in the region. Indeed, in Latin America, the average population density is 21 inhabitants per square kilometre (ranging from 257 in El Salvador to six in Bolivia), less than a fifth of the average for the European Union of the fifteen (EU-15), slightly below Sub-Saharan Africa and well below the other developing regions. In the case of its dispersed population, ${ }^{2}$ Latin America as a whole has 6.7 inhabitants $/ \mathrm{km}^{2}$ while several countries have less than half this (namely Argentina, Bolivia, Chile, Uruguay and Venezuela). This is considered extremely low by European standards (Persson and Ceccato, 2001). The importance for RNFE configuration of this low population density and the "distances" that come with it is one of the points that we will try to emphasize, if not demonstrate, in this article.

\section{III}

\section{Reasons for the growth of rural non-farm employment}

According to data from Latin American population censuses, RNFE appears to have grown from some $17 \%$ of the rural economically active population (EAP) in the 1970 s to $24 \%$ in the 1980 s, that is an annual increase of $4.3 \%$, while the agricultural EAP increased by only $0.03 \%$ per year. In fact, agricultural employment

\footnotetext{
${ }^{2}$ Calculated on the basis of $90 \%$ of total surface divided by the number of inhabitants in localities of less than 2,000 people. The calculation is rather conservative since the United Nations Centre for Human Settlements (UNCHS, 1996, p. 418) estimates that in most countries urban areas do not exceed $1 \%$ of the national territory.
}

growth was negative in nearly half of the Latin American countries, while RNFE growth was positive in all countries. ${ }^{3}$ RNFE grew substantially once again in the 1990s, as will be seen in the next section.

Poverty has remained more or less stable (in percentage terms) for decades now in rural Latin America. Therefore, it can be stated that RNFE as a whole did not grow in response to increased poverty,

\footnotetext{
${ }^{3}$ Reardon, Berdegué and Escobar (2001), on the basis of figures from Klein (1992)
} 
although evidence shows that a large proportion of rural microenterprises are created as a palliative against deeper poverty.

Rural population has also remained more or less stable over the past decades, as has farm employment. There has, however, been a shift of residence for those working primarily in agriculture, as they increasingly live in urban areas. This is true of both recent migrants, who find fewer barriers to employment as casual agricultural labourers than in the urban labour market (Hataya, 1992), and better-off farmers who continue farming but move to more urban areas (Berdegué, Ramírez and others, 2001). This does not at first sight explain RNFE growth.

Agriculture in the region has grown at a fairly robust average of $2 \%$ to $3 \%$ over the last three decades. No similar calculations have been made for the rural economy to my knowledge, but it can probably be conjectured that this has grown by at least the same amount. Therefore, rising RNFE could be a "normal" response to growth as well as a response to increased demand for services from agriculture as it modernizes. Why these services would be provided by rural residents while farmers move to urban areas remains an open question.

Another reason may be the rural young to middleaged males who decide to continue residing in rural areas (because of housing, their attachment to family life, their preference for rural living, etc.) but do not wish to farm or have no access to farmland (Dirven, 2002), and thus apply for or "create" a rural non-farm job or commute daily to an urban area if distance permits.

Yet another explanation is the entrance of (mostly young) rural women into the labour force. They then face the same choices as young men: migrate, stay on outside the farm sector or commute.

A recent finding - which requires further research, but which is probably closely related to the previous two points and RNFE location, to which we will return later- is that younger people seem to concentrate i) around more dynamic areas, both near small rural towns or hamlets that have shown economic dynamism or those that have been the focus of recent government investments, often related to poverty alleviation or decentralization policies; or ii) along paved roads leading to these more dynamic centres. ${ }^{4}$

\footnotetext{
${ }^{4}$ These findings are based on a visual interpretation of the maps prepared by Pablo Ávalos as part of his internship at the ECLAC Agricultural Development Unit and in preparation of his thesis as a
}

This brings us to the importance for RNFE growth of the decentralization and rural development policies that were implemented in most countries of the region in the 1990s. These have led to the creation of new jobs in municipalities and regional governments as well as in health, education, credit, technical assistance, infrastructure and other services. In fact, even extremely undynamic municipalities in areas undergoing severe desertification and with clear net out-migration patterns are actually attracting new migrants, of all ages and many employment category profiles, although with a preponderance of government civil servants and consultants, technicians and volunteers with non-governmental organizations (Morales, 2003).

Increasing demand from tourism and well-to-do urban second home owners at weekends and during vacations is yet another explanation, as is the presence of peri-urban first home dwellers, some relatively well off and others poor, who wish to live within "reasonable" commuting distance and time from urban areas and benefit from country living or cheaper accommodation. $^{5}$

De Janvry and Sadoulet (1993) ${ }^{6}$ suggest that the extremely unequal distribution of assets in Latin America (worse than in any other continent) most probably has a negative effect on the creation of local linkages. Indeed, because of the highly skewed distribution of income and land (Gini coefficients of around 0.60 and 0.80 , respectively), a small number of landlords receive most of the income benefits of agricultural growth. Most of them are absentee landlords and therefore most of this income does not increase local demand. However, this finding does not alter the fact that the relatively large modern agricultural sector in Latin America uses more inputs and services than the agriculture of other developing regions and therefore generates relatively strong linkages to the rest of the economy, albeit not so much locally (de Janvry and Sadoulet, 2002, p. 18). Calculations carried out in 2003 by the Inter-American Institute for Cooperation on Agriculture (IICA) point to agricultural multipliers of around 3 for several countries of the region. Compared

geographer at the University of Chile. Ávalos prepared a series of maps of Chile's VI, VIII and IX Regions, using the Retrieval of data for small areas by microcomputer (Redatam) software developed by ECLAC/CELADE to compare 1992 and 2002 population census age and gender structure data at the censal district level.

5 See Graziano da Silva and del Grossi (2001), among others.

${ }^{6}$ Mentioned by Lanjouw (2001). 
to the multipliers of developed countries (a multiplier of 11 was found for the United States in the same study), these are of course still quite modest. How much of all this translates into RNFE and under what conditions is not clear as yet. This is definitely a point on which further research should be done.

\section{IV}

\section{Rural non-farm employment in figures: a snapshot of the late 1990s}

RNFE for 11 Latin American countries ${ }^{7}$ was calculated on the basis of an expansion of 1999 household survey figures. Together, these countries represent approximately $72 \%$ of Latin America' ${ }^{8}$ economically active population (EAP, that is the working and unemployed population). The finding was that around $39 \%$ of the working rural population were in RNFE (tables 1 and 2). This is a substantial increase over previous estimates for the early to mid-1990s, which ranged from about $30 \%$ to $35 \% .{ }^{9}$ To obtain table 1 , use was made of the answers to the household survey question: "what was your main occupation last week?"10 The total figure obtained, especially the one referring to women, substantially exceeds the ECLAC/ CELADE (1999) ${ }^{11}$ economically active population projections for the year 2000 (which include the $2 \%$ to $3 \%$ of the rural population that is unemployed). There are three possible explanations for this: i) a methodological one: the CELADE figures are based upon population censuses that capture employment less well than household surveys, especially in the case of women; ii) more women entered the labour force than

\footnotetext{
${ }^{7}$ Countries with national coverage household surveys and for which the microdata were available at ECLAC, namely: Bolivia, Brazil, Chile, Colombia, Costa Rica, El Salvador, Honduras, Mexico, Nicaragua, Panama and Paraguay.

8 In addition to the countries lying between Mexico and Chile/ Argentina from North to South, "Latin America" includes Cuba, the Dominican Republic and Haiti, but excludes the English-speaking Caribbean countries, Belize and Guyana.

9 See, among others, Dirven (2000) and Reardon, Berdegué and Escobar (2001).

${ }^{10}$ In some countries the reference period is the last month. The surveys are extremely sensitive to the time of implementation and the period covered. In Brazil, for example, 14.6 million people responded that agriculture had been their main activity in 1997 . When the reference period was the last week of September of that same year, only 13.4 million gave the same response (Graziano da Silva and del Grossi, 2001).

11 ECLAC Population Division, formerly Latin American and Caribbean Demographic Centre (CELADE).
}

the projections allowed for, or iii) a phenomenon similar to that of the 1980s has taken place; namely, rural-urban migration flows tapered off as a result of the new "lost half-decade" (1998-2002) and the 1999 household surveys captured this.

The working population in the 11 countries analysed totals some 140 million, of whom $30 \%$ are rural. Of the urban employed, some $6.6 \%$ have agriculture as their main occupation (especially those aged over 45), while some $39 \%$ of the rural employed engage in non-agricultural activities (especially those aged under 45 , and most particularly those aged 30 to 44$)$.

In both rural and urban areas, female participation in non-agricultural activities is higher than in agricultural activities. ${ }^{12}$ Women accounted for $44.4 \%$ of RNFE and $41.2 \%$ of urban non-farm employment, as against $27.3 \%$ of rural farm employment and $25.2 \%$ of urban farm employment.

In previous studies, Dirven (2000 and 2002) showed that over-60s (men and women) were much more strongly represented in the rural EAP $(8.3 \%)$ than in the urban EAP $(4.6 \%)$. This is explained by the weight of the agricultural EAP in the rural EAP and the fact that $10 \%$ of the agricultural EAP is more than 60 years old. In turn, the rural EAP contains a smaller share of 30- to 44-year-olds, owing to migration. The 15- to 29-yearold group is equally well represented in rural and urban areas because, on the one hand, working life starts earlier in rural areas but, on the other, this is a group in which migration is especially prevalent.

\footnotetext{
12 This is partly due to under-reporting, although ILo has made great efforts to encourage the use of specific questions relating to female on-farm work to get around this. As a result of these efforts, the FAO agricultural EAP figures for Latin America rose from 40 million to 44 million people from one database to another in the mid-1990s.
} 
Latin America (11 countries): Estimated working population in rural and urban areas, 1999

\begin{tabular}{|c|cc|}
\hline Total 140141814 & $=100.0 \%$ \\
\hline $\begin{array}{c}\text { Urban: } 97601576 \\
69.6 \%\end{array}$ & $\begin{array}{c}100.0 \%=\text { Rural: } 42540238 \\
30.4 \%\end{array}$ \\
\hline
\end{tabular}
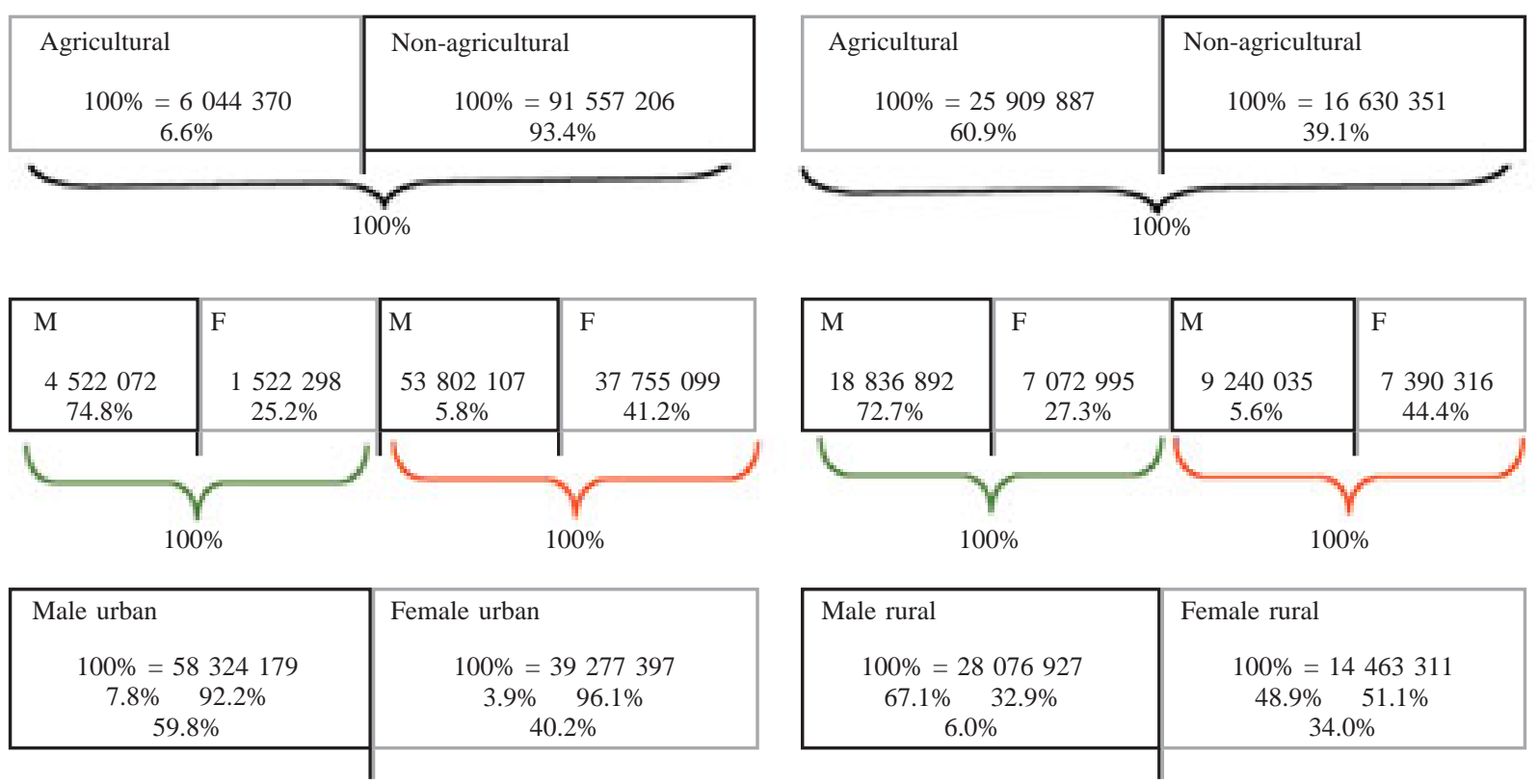

Source: Prepared by the author on the basis of 1999 extrapolations of the household surveys of Bolivia, Brazil, Chile, Colombia, Costa Rica, El Salvador, Honduras, Mexico, Nicaragua, Panama and Paraguay. The extrapolations were carried out by the Women and Development Unit of ECLAC

TABLE 2

Latin America (11 countries): Urban population working in agriculture and rural population working in agriculture and in rural non-farm employment (RNFE)

(Number of people and percentages)

\begin{tabular}{|c|c|c|c|c|c|c|c|c|}
\hline & \multicolumn{2}{|c|}{ Urban } & \multicolumn{4}{|c|}{ Rural } & \multicolumn{2}{|c|}{ Total rural } \\
\hline & Agric. & $\begin{array}{c}\text { Women } \\
(\%)\end{array}$ & Agric. & $\begin{array}{c}\text { Women } \\
(\%)\end{array}$ & RNFE & $\begin{array}{c}\text { Women } \\
(\%)\end{array}$ & & $\begin{array}{c}\text { Women } \\
(\%)\end{array}$ \\
\hline Bolivia & 75066 & 25.8 & 1192603 & 45.9 & 202024 & 45.5 & 1394627 & 45.9 \\
\hline Brazil & 4476541 & 27.8 & 11689984 & 36.7 & 4239238 & 44.3 & 15929222 & 38.7 \\
\hline Chile & 279070 & 19.6 & 456893 & 10.9 & 235594 & 39.3 & 692487 & 20.5 \\
\hline Colombia & 298067 & 12.3 & 3183960 & 11.5 & 2462521 & 49.1 & 5646482 & 27.9 \\
\hline Costa Rica & 30791 & 8.8 & 220977 & 7.7 & 425662 & 36.3 & 646639 & 26.5 \\
\hline El Salvador & 72870 & 9.1 & 399037 & 7.5 & 386139 & 48.1 & 785176 & 27.5 \\
\hline Honduras & 84390 & 10.1 & 647926 & 6.0 & 448022 & 59.7 & 1095949 & 27.9 \\
\hline Mexico & 536329 & 23.3 & 6974498 & 22.5 & 7528597 & 42.3 & 14503095 & 32.8 \\
\hline Nicaragua & 95120 & 13.5 & 445780 & 9.8 & 229823 & 49.8 & 675603 & 23.4 \\
\hline Panama & 47465 & 4.0 & 121666 & 3.6 & 127608 & 38.7 & 249274 & 21.6 \\
\hline Paraguay & 48660 & 17.4 & 576563 & 20.5 & 345121 & 45.7 & 921684 & 29.9 \\
\hline Total & 6044370 & 25.2 & 25909887 & 27.3 & 16630351 & 44.4 & 42540238 & 34.0 \\
\hline
\end{tabular}

Source: Prepared by the author on the basis of 1999 extrapolations of household surveys carried out by the Women and Development Unit of ECLAC. 


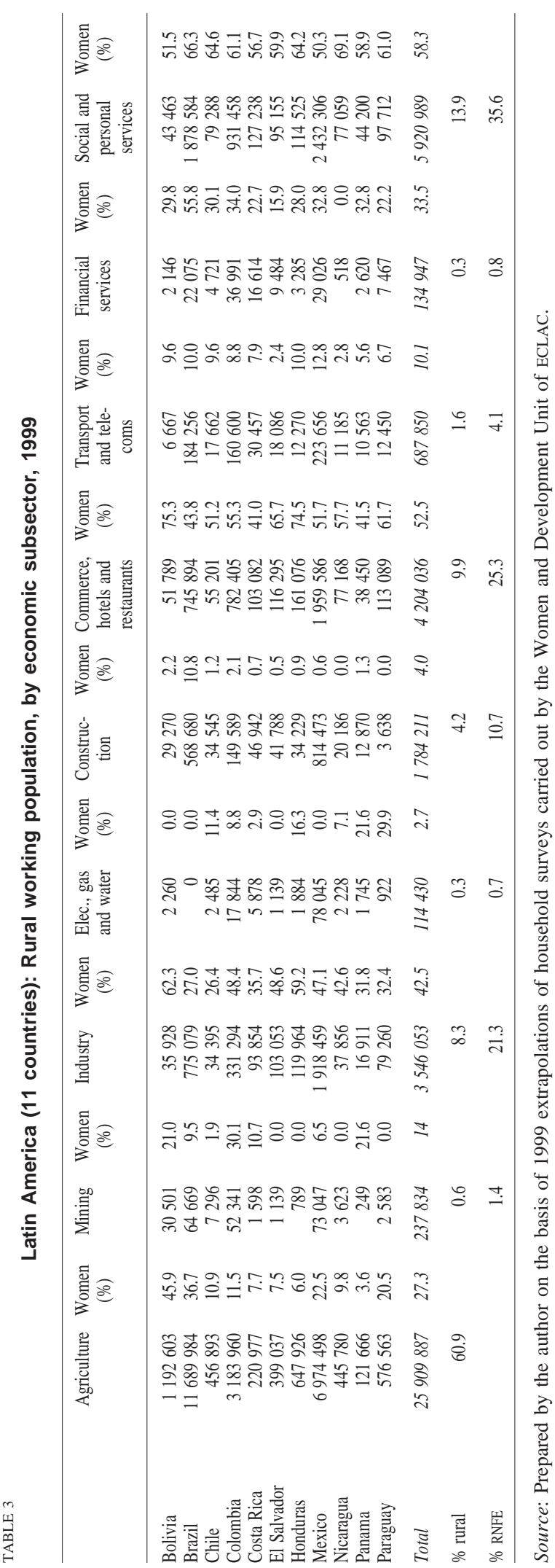

The rural non-agricultural female EAP is very youthful, with almost half being aged from 15 to 29 . As many as $51 \%$ of all working women in rural areas are in RNFE, while the figure for men is $33 \%$.

Employment-wise, the most important sectors are i) social, communal and personal services; ii) commerce, hotels and restaurants, and iii) manufacturing, accounting respectively for $36 \%, 25 \%$ and $21 \%$ of total RNFE. Interestingly, all three are also characterized by a strong female participation of $51 \%, 53 \%$ and $43 \%$, respectively (table 3 ).

Reardon, Berdegué and Escobar (2001) found that $46 \%$ of the income of Latin American rural dwellers came from non-agricultural activities, i.e., a larger proportion than is represented by RNFE as a main activity. On average, then, RNFE seems to have higher productivity than agricultural activities. It should be noted, though, that often all non-farm income is computed, including transfers (governmental and private). In addition, some portion of RNFE is in secondary activities, while the figures for those in work refer to the main activity alone. Both lead to the average productivity of RNFE being overestimated. Just how much is illustrated by, for example, Berdegué, Ramírez and others (2001) for Chile. They found that transfers amounted to $35 \%$ of total income in a poor rural municipality (Portezuelo), and made up 22\% of income for the landless and $12 \%$ for those with land in a richer rural municipality (Molina).

RNFE can be divided, however, between lowproductivity "poverty refuge" activities that generate low income, have low entry and exit barriers and are essentially supply-generated, on the one hand, and dynamic, higher-productivity activities ${ }^{13}$ that are more demand-generated but have relatively high entry barriers (in terms of both financial and human capital), on the other. In most instances, the contribution of RNFE income to total income versus household assets (especially land) forms a U-curve, while total RNFE income usually rises with the level of different assets (land, education, capital, and also access to roads and other infrastructure, as well as proximity to markets, or rather to larger settlements).

\footnotetext{
${ }^{13}$ Most authors distinguish between "high" and "low" productivity RNFE. We have preferred to use "higher", a relative concept as compared to "low" and not to be confused with genuinely highproductivity and high-income employment in which, unfortunately, very few rural Latin American residents are engaged. In fact, as Wiggins (2003) shows for Mexico, rather than two tight categories of RNFE incomes, there is a continuum that goes from very low to relatively high incomes.
} 
Latin American rural labour markets are far from perfect and shadow wages often differ from market wages. They are determined by the marginal productivity of labour, but also by the price of consumer goods, transaction costs, available time, nonlabour income and private and public asset endowment, as well as the non-separability of some production and consumption decisions. Decisions about the allocation of labour between wage and self-employment activities in agriculture or RNFE therefore depend on all these issues.

In what follows, we shall draw mainly upon information contained in World Development (2001) in an attempt to move from a "flat, indefinite picture" of "rural" life to a much richer description, with emphasis on "distances".

\section{V}

\section{Assets and rural non-farm employment}

\section{Private assets}

a) Land

Concerning the relation between household land assets and RNFE, evidence seems to be mixed. Although in many cases the U-curve mentioned earlier holds, Reardon, Berdegué and Escobar (2001) find rather that the share of total household income from RNFE falls as landholdings rise, since those with more land have less of an incentive to depend on RNFE. On the other hand, evidence shows that the level of RNFE earnings increases with household income.

The overview provided in the special edition of World Development (2001) indicates that in Peru (Escobal, 2001) and Mexico (Yúnez-Naude and Taylor, 2001) the ownership of fixed agricultural assets increases the share of farm income in total household income and reduces the need for wage employment, be it agricultural or non-agricultural. In Mexico, it also reduces migration. ${ }^{14}$ In turn, stockbreeding, which is less labour-intensive, increases a household's RNFE income share and an additional household member increases the probability of wage income.

In Honduras, on the other hand, participation in self-employment is relatively independent of the size or use made of landholdings, but RNFE wage labour is positively related to farm size, especially in the northern region (where most industrial free trade zones have been established) and when part of the household's land is irrigated and mechanization reduces labour requirements (Ruben and Van den Berg, 2001).

\footnotetext{
${ }^{14}$ Migration to the rest of Mexico or to the United States is highly correlated with the educational level of the individual (less or more than three years of primary education, respectively) (Yúnez-Naude and Taylor, 2001).
}

A possible interpretation of this mixed evidence is that, depending on location and "distances", households with sufficient land to create a surplus for reinvestment either do this in RNFE when well located, or in agriculture and additional land when faced with distance constraints.

\section{b) Savings and access to credit}

The poor functioning of rural financial markets in developing countries can be ascribed not only to imperfect information, high transaction costs and illdefined property rights that limit formal credit, but also to a failure to capture the savings of rural households. Often, then, these households cannot obtain positive returns on their savings except by investing them in a home-based enterprise (Lanjouw, 2001). Rural nonfarm income may thus derive from savings turned into investments, while at the same time RNFE income is often sought as a way of coping with credit restrictions.

In line with the foregoing, in El Salvador the great majority of rural non-agricultural enterprises state that their start-up capital came from personal savings. In fact, only $7 \%$ of the enterprises were originally financed by formal credit sources (Lanjouw, 2001). In Peru, access to credit is an important determinant of self-employment (be it in the agricultural or nonagricultural sector), while in Honduras the search and transport costs involved in finding rural non-farm wage employment or the funds needed to initiate RNFE activities are usually financed by household or personal savings, or informal credit. Put differently, without savings or access to formal or informal credit, RNFE is difficult to come by, either because of search costs or investment requirements. It is however important to note that in Peru and Honduras, as in other countries, non-agricultural income sources serve as substitutes for 
extremely limited formal credit, relieving capital restrictions (Escobal, 2001; Ruben and Van den Berg, 2001).

In general, studies on RNFE tend implicitly to have self-employment or wage employment in micro- to small-scale enterprises ${ }^{15}$ in mind when conducting their analyses. As a result, they insufficiently stress employment in government services (education, outreach, technical assistance, social and health services, local administration, etc.), whose search costs differ from those for private-sector employment. Reardon, Berdegué and Escobar (2001) state that public-sector RNFE is generally quite low in the Latin American countries analysed. We are not convinced that this is correct, and this issue should be looked into further. In Chile, for example, government-related employment accounts for a not-so-small $16 \%$ of total RNFE (respectively: education, $8 \%$; public administration including defence, 6\%; and social and health services, $2 \%$ ). In Brazil, some $70 \%$ of people employed in the "social services" category work in State schools and $8 \%$ in public health. The rest are employed in sports organizations, private clinics and schools and social assistance services of various kinds (Graziano da Silva and del Grossi, 2001).

\section{c) Education and experience}

The relationship between education and the more productive types of RNFE is unmistakably positive, as all the studies point in the same direction. Less productive RNFE, however, usually does not show any significant correlation with education levels, albeit know-how and experience are unquestionably assets.

In north-east Brazil, finishing primary education ${ }^{16}$ increases the probability of RNFE participation by two percentage points in comparison with an illiterate person, all other variables being constant. With a complete secondary education this probability is 24

\footnotetext{
15 Wiggins (2003) points to the fact that categorizing activities as either "waged" or "self-employed" can be misleading, since many self-employment jobs are carried out so flexibly to customer requirements that they are tantamount to wage labour; the author then goes on to give the example of the farm hand and the painter, each bringing their own tools (respectively, machete and brush), each paid by the day, each usually directed by the contractor as to some of the specifics of the work, but one being considered a wage labourer and the other self-employed.

${ }^{16}$ It should be noted that Brazil has among the lowest average rural education levels in Latin America and that these are even worse in the north-east than elsewhere. On average, $63 \%$ of Brazil's rural population aged between 15 and 24 has five years or less of primary education, while among those aged between 25 and 59, $83 \%$ have spent five years or less at school (ECLAC, 2001).
}

percentage points higher. The same trends can be observed in south-east Brazil. When RNFE is divided between higher- and low-productivity activities, this is much more evident still (Ferreira and Lanjouw, 2001).

In Mexico, the positive relationship between education and income (from both agriculture and RNFE) becomes especially visible when the household has an additional member with more than nine years of formal education. This causes a large increase in wage income of around US\$ 780. By contrast, an additional household member with incomplete primary education (1 to 3 years) is associated with the production of staple goods, since people with this level of education have no choice but to engage in a traditional activity such as maize-growing (Yúnez-Naude and Taylor, 2001).

In Ecuador, education is again closely associated with RNFE. Households have a higher probability of being engaged in rural non-farm enterprises when at least one member has formal primary or secondary schooling. Additionally, if all household members have some education the probability of being involved in a rural non-farm business is much higher still, while those with post-secondary education are more likely to be involved in wage labour than to establish a family business (Elbers and Lanjouw, 2001).

In Peru, the effects of education are very clear as well: the higher the formal education level, the less the incentive to obtain income from the family plot and the greater the incentive to engage in RNFE, be this selfemployment or wage employment. Data indicate that skilled labour receives around 30\% more wage income than unskilled labour in agriculture, and around 50\% more in RNFE. However, this difference is only noticeable on the coast, while in the highlands (altiplano) and the Amazon region there is hardly any difference. Escobal (2001) interprets this as being due to relatively underdeveloped labour markets in those regions.

In Nicaragua, people who do not own land but have high education levels earn high RNFE incomes in activities such as teaching, particularly if they live near roads and towns (Corral and Reardon, 2001).

Interestingly, what Schultz (1964) concluded for agriculture in general and, later, Figueroa (1986) for Latin America, also seems to hold true for RNFE, namely that the returns to an additional year of education are not the same in a poor, lethargic zone as in a richer, dynamic one. Thus, Berdegué, Ramírez and others (2001) found that more educated workers in Portezuelo (a lethargic rural municipality) tended to do the same tasks as less educated ones in Molina (a dynamic rural 
municipality), and that in Molina there were more opportunities for people with more education. In fact, figures for several Latin American countries show that people working primarily in RNFE have more years of formal schooling than rural residents employed primarily in agriculture, but a similar number to urban residents employed primarily in agriculture. Urban residents employed primarily in non-agricultural activities have the highest educational levels. ${ }^{17}$

\section{d) Household members}

The farming household is an important decisionmaking unit in many settings. It is distinguished by the fact that it is both a producer and a consumer of a range of goods. Food products and family time (used as labour or leisure) are common examples of such goods. In theory, the household will maximize in a two-step process that is recursive and hence separable. It will first maximize profits as a producer, which will maximize household income, and then it will allocate its income so as to maximize utility as a consumer. The separability of the maximization process depends, however, on whether or not there are differences between the market prices of production/consumption goods and the value of those goods within the household (their shadow prices). Shadow price endogeneity ${ }^{18}$ may arise under a wide range of circumstances. It is potentially present whenever the market for at least one production/consumption good is "imperfect", i.e., when the household is not a pricetaker, when it views the good sold in or purchased from the market as an imperfect substitute for the good that is produced and used on the farm, and/or when it faces gaps between purchase and sales prices (due to transaction costs). It also occurs when household labour on and off farm are distinct arguments in the household utility function. Similarly, shadow-price endogeneity follows when no household labour works off farm (despite having the option to do so) in a situation where family and hired labour are separate arguments in the household production function (Löfgren and Robinson, 1999).

In both Honduras and El Salvador, households apparently first use family labour for covering their self-produced staple food requirements and only then engage "supernumerary household members" in RNFE.

\footnotetext{
${ }^{17}$ Results of special household survey tabulations run at ECLAC. ${ }^{18}$ That is, the price of a good that is determined not by the market but endogenously by the interaction between household demand and supply.
}

Therefore, household size has a positive influence on the probability of a household member engaging in RNFE. RNFE is important as an income diversification strategy when there are sufficient resources to replace the more educated family members who can obtain higher incomes outside agriculture (Lanjouw, 2001; Ruben and Van den Berg, 2001).

In Brazil, by contrast, household size does not seem to be correlated to RNFE. In fact, the data even suggest that in a household which specializes in agricultural activities (i.e., which has a high percentage of its members in agriculture), it is unlikely that any members will go to work in a non-agricultural activity (Ferreira and Lanjouw, 2001).

The principal type of RNFE varies by income stratum. Middle-income households ${ }^{19}$ are mostly active in non-agricultural wage labour, high-income households are self-employed in RNFE or have small and medium-sized RNFE enterprises, while poor families are mostly employed in agricultural wage labour activities with some additional non-agricultural income from activities such as handicrafts or petty trading. This is in line with the capital accumulation that usually takes place over the life cycle and the capital requirements of RNFE. The corollary of all this is that, in order to increase their participation in RNFE, rural households need to i) overcome financial barriers to entry, and ii) have access to labour-saving technologies or the possibility (investment-wise) of such access, or iii) have a large household. RNFE probability increases with age until about 40 and then decreases, although in Honduras it is older people that tend to access wage RNFE and age has an important positive effect on nonfarm income, most probably implying that RNFE requires both higher qualifications and experience. ${ }^{20}$

As to gender, the figures for the 11 Latin American countries analysed show that men represent somewhat more than half of total RNFE $(56 \%)$. However, as already mentioned, because women are much less active in agriculture than men (at least as per the official figures), the proportion of women in RNFE as compared to the total female rural EAP is much higher (about 51\%) than for men (about 33\%). Men who are not household heads tend to work in wage labour, while women and male household heads tend to work on their

\footnotetext{
${ }^{19}$ With $38 \%$ of households living below the indigence line and $64 \%$ below the poverty line in rural Latin America (ECLAC, 2002), this is a relative concept.

${ }^{20}$ Ruben and Van den Berg (2001), Dirven (2000), Ferreira and Lanjouw (2001) and Corral and Reardon (2001).
} 
own account. Men and women are active in different sub-sectors, however. Men work essentially in construction, transport and heavy manufacturing, and women principally in administration, the textile industry, education, own-account activities and personal and domestic services (table 3). In general, women are more likely to be self-employed but tend to earn much less than men, all other characteristics being equal; up to $29 \%$ less in El Salvador, for example, according to Lanjouw (2001).

Controlling for other characteristics, the probability of RNFE participation does not seem to be associated with race in Brazil, contrary to the experience in other countries (Ferreira and Lanjouw, 2001). In Mexico, it is harder for indigenous people to get access to RNFE than for their non-indigenous peers with a similar level of education; in addition, there is a substantial educational gap between the two groups (de Janvry and Sadoulet, 2001). A possible explanation that goes further than mere discrimination, although this certainly exists, is that there tends to be a significant correlation between membership of indigenous groups and residence in more remote areas, with low population densities and less RNFE (Corral and Reardon, 2001).

Another interesting finding, at least in Brazil, is that individuals still living in the municipality where they were born are slightly less likely to participate in RNFE (Ferreira and Lanjouw, 2001). A parallel can be drawn with findings that indicate greater openness to innovation (and its risks) among return migrants (from the capital, Lima) in Peru and ex-soldiers (or guerrilla fighters) in Central America and Colombia. The fact of having been exposed to experiences and activities different from those they would have encountered in their home village seems to bring about a change in mentality and abilities that affects investment and labour decisions, among other things.

\section{Public goods, infrastructure and other location assets}

\section{a) Dynamism in agriculture}

The great variety of linkages between the nonagricultural and farm sector and the different forces underlying them have been the object of considerable theoretical and empirical analysis. Johnston and Kilby (1975), and many others, have maintained that a virtuous circle can arise from the intensification of agricultural and non-agricultural activities on the basis of production and consumption linkages. In principle, of course, this is so and most studies point that way. However, the foreign trade and investment liberalization policies followed to different degrees by all Latin American countries from the mid-1980s, plus improvement to transport networks, have increased the scope for strengthening non-local linkages, resulting in the partial "leakage" of local effects to the "rest of the world"; either to elsewhere in the national economy, or to foreign economies. The contrary is true too, and there is also more likelihood of external "engines" kindling local dynamism.

We share Elbers and Lanjouw's (2001) opinion that the traditional growth model in which Lewis points to intersectoral transfers retains all its relevance when it is recognized that the modern non-agricultural sector can develop just as well in rural as in urban areas. Data indicate that this process tends to increase inequity, but this should not be interpreted as meaning that the poor do not benefit. Also, the possibility that it is the agricultural sector which is the force behind changes in welfare, as well as in RNFE patterns, cannot be ruled out.

Several of the authors of the studies reviewed in this article find strong linkages. Thus, Escobal (2001) finds that, in Peru, the higher the land productivity in a certain district, and thus the more vigorous the local agricultural sector, the greater the share of nonagricultural income in total income. Ruben and Van den Berg (2001) conclude that microenterprises in Honduras have important linkages with the agricultural sector, be it through the provision of inputs (backward linkages) or the transformation of products or their distribution to (mostly) rural consumers (forward linkages).

Lanjouw (2001) is more cautious and states that with the data available for El Salvador it is difficult to verify the strength of backward and forward linkages due to an increase in agricultural income. He does conclude though that these linkages are present (i.e., both those stemming from agriculture and those from consumption), because a large proportion of nonagricultural activities are somehow centred around trade, food preparation, transport and repair activities.

In Chile however, in two different rural municipalities, one (Molina) with much more dynamic agriculture than the other (Portezuelo), the income generated in RNFE is less linked to agriculture (only $22 \%$ ) in Molina than in Portezuelo (57\%), and average incomes from RNFE are higher when less linked with agriculture. Indeed, RNFE productively linked in a direct way to agriculture, such as agro-processing, generates returns only $33 \%$ to $43 \%$ as high as those for RNFE not linked in this way. In addition, earnings from nonagricultural activities carried out by rural households in rural areas are only about $70 \%$ as high as those from 
such activities carried out in urban centres. The latter, though, help generate a large influx of income into rural areas (Berdegué, Ramírez and others, 2001).

To explain the types of linkage that take place, a recent study on dairy clusters and value chains in several Latin American countries (Dirven, 2001) clearly showed the relevance of von Thünen's nineteenth-century theory on land value gradients, on the one hand, and the type of enterprises (micro, small, medium, large national or transnational) that participate in each node, on the other. Thus, near large cities, dairy farms use land much more intensively and therefore have a much more intensive use of inputs of all kinds. As a consequence they have far more backward linkages to production and services than dairy farms in more remote regions, albeit often with importers rather than local input producers. Secondly, industrial processes also vary in relation to location, with the production of high-value yoghurt, fresh cheese and liquid milk near the largest cities and of ripened cheeses and powdered milk in more remote milk-producing areas, while in tropical zones these latter products are made using milk from dual-purpose cattle (meat and dairy). Obviously, the resulting linkages to machinery, transport, packaging and other input providers are extremely different. Whether farms, agro-industry or input and service providers are microenterprises or multinationals (or somewhere in between) also has significant effects on technology use and the resulting linkages (Dirven, 2001). The integration of agriculture and its linkages with the effects of distance, and the combined impact of these on RNFE, have not received much attention in the literature as yet.

\section{b) Roads and other infrastructure}

In general, RNFE in Latin America seems to be closely linked to location. The level of non-agricultural earnings is determined above all by the economic context, in particular the level and dynamism of the economy in the particular locality or territory, but also by the quality of roads. Access to good roads is especially important for participation in agricultural and non-agricultural wage employment. It seems to be less important in own-account non-agricultural activities, however. Data so far indicate that rural own-account activities are dominated by small enterprises, mostly run by women, which serve local rural markets (Berdegué, Ramírez and others, 2001; Corral and Reardon, 2001).

In particular, there are clear signs that RNFE is more dynamic in areas that are well connected to markets and endowed with at least a minimum of standard infrastructure (Ferreira and Lanjouw, 2001). ${ }^{21}$ Thus, access to public assets like rural electrification and roads noticeably increases overall income, from agriculture but above all from non-agricultural activities (Escobal, 2001). The correct interpretation probably is not that roads are less important for agriculture, but rather that due to von Thünen's "law", agriculture adapts to areas that are less close to main roads, while non-agricultural activities often have to be located nearer to them and near to rural-urban concentrations (Corral and Reardon, 2001). In general, however, few rural enterprises have access to this basic infrastructure. Thus, in El Salvador, 35\% of enterprises stated that they had difficulties with transport due to bad road conditions and very few had a telephone connection. And while access to infrastructure seems to have had similar effects on RNFE in El Salvador as those noted above, and low-productivity RNFE seems to have been more concentrated around small rural hamlets and other settlements, surprisingly this does not seem to have influenced remunerations significantly and, in the case of higher-productivity RNFE, distance does not seem to have played an important role (Lanjouw, 2001). As noted earlier, though, El Salvador is densely populated, unlike most other countries in the region.

\section{VI}

\section{“Distances” and rural non-farm employment}

\section{Territories and location}

As can be inferred from the previous section, and as is indeed slowly taking place in the region, rural development and rural poverty alleviation policies
21 The anonymous reviewer who commented on this article pointed out that investments in roads and other infrastructure often follow more dynamic activities and that the cause-effect relationship of infrastructure and RNFE should therefore be interpreted with caution. No doubt he has a point. 
should explicitly consider the heterogeneity of territories. A recent overview of rural territorial development in Latin America (Schejtman and Berdegué, 2003) distinguished four types of territories, each the result of different historical, socio-economic and institutional trajectories and potentials, and therefore calling for different sets of policies. They are: i) territories that have made progress with productive development and attained a degree of institutional development that permits of a reasonable degree of social dialogue and inclusion; ii) territories that have experienced significant economic growth which has, however, had little impact on local development and, in particular, on the opportunities of their poorest segments; iii) territories with strong institutions, often expressed through a strong cultural identity, but lacking in endogenous economic options capable of sustaining long-term poverty alleviation processes, and iv) territories that are clearly undergoing a process of social and economic destructuring.

This typology was designed for territorial development policies. It undoubtedly has its uses as well for explaining RNFE types found in these territories, as RNFE both influences and is influenced by the type of territory in which it takes place. One of its shortcomings, however, is that the authors did not explicitly take into account the location of the territory and therefore its distance to markets. Slowly, influenced among others by Krugman, economists are starting to look again at location as an explanatory factor in economic development.

Wiggins and Proctor (2001) put it this way: "Around most cities lies a peri-urban zone of intense interaction with the city, an area that might be defined as that where people may commute daily from village to city for work. Beyond lies a countryside where distance prevents daily commuting, and the cost of movement to and from the city is significantly greater. Further away still, there are rural areas that are remote, cut off by lack of infrastructure, great distance, and physical obstacles. Here, the costs of movement of goods and people to and from urban areas are unusually high. ${ }^{22}$ Note that density of settlement will usually correlate positively with closeness to the cities (and the natural wealth of the area)." The authors then

\footnotetext{
${ }^{22}$ Markets can even "fail" for a particular person or household when the difference between the selling price and the buying price of a specific good is too large. In such a case, the household may be better off producing the good for self-consumption (Escobal, 2000; Key, Sadoulet and de Janvry, 2000).
}

superpose natural resource quality upon location (periurban, middle-distance countryside and remote rural) to arrive at a table with six types of locations and resources (land quality, natural beauty, etc.) indicating the likelihood of certain types of activities being found in certain places (or, seen from another angle, the territory's development potential). In addition (and especially in Latin America, with its highly skewed income and asset distribution), availability of and control over assets, particularly land, also play an important role in each of these settings.

\section{2. "Distances" and transaction costs}

Location is crucial because it plays a determining role, together with infrastructure, in the distance to markets. Distance here is understood as physical distance weighted by transaction costs. A study in Peru (Escobal, 2000) calculated the transaction costs for the sale of agricultural goods, potatoes in this case, for two districts of Huancavelica. On average they were equivalent to around $50 \%$ of the value of the goods sold. For farmers connected to the market via a trail they were $60 \%$ higher than for those connected via a road that was practicable for cars all year round. The study also confirmed that transaction costs were much larger for small farmers than for larger-scale ones $(67 \%$ versus $32 \%$ of the sales value, respectively).

There are several other "distances" that play a role in transaction costs, however. Escobal (2000) showed that farmers' decisions were influenced not only by the cost and time involved in reaching a market, but also by their experience in a particular market, the stability of relations with buyers, and the resources invested to obtain information and supervise implicit contractual arrangements.

A study on "organizational distance" in Peru showed that rural organizations and institutions had a marked tendency to relate to organizations of the same kind. This means that professionals and technicians do not see the organizations of the community as equal partners. This tendency to establish relationships with peers introduces an additional exclusion factor for the poor and the more rural (Andersen, 2003).

Social and cultural 23 "distances" also play a fundamental role in transactions involving goods,

\footnotetext{
23 Primi (2002) defines cultural distance as the differences in language, concepts, logic, ideas, beliefs and values between different households, social groups and localities.
} 
labour, services and ideas. The location of households within the hamlet, district or region is also crucial in this two-way interaction of causes and effects. The social and economic isolation that may result from these different "distances" can be quite marked, even between households in the same locality, because of the great dispersion that characterizes many rural localities. And because "distances" increase information asymmetries, the poor and isolated (who already have little choice as to where, with whom and at what price to trade) will participate in the different markets on unequal terms (Primi, 2002).

In sum, the decision to offer or use labour or investment resources for RNFE rather than for agriculture or migration is determined by the expected wage or income minus the transaction costs (information, "supervision of the contract" or risk that the expected contract will not materialize or will be discontinued before long, transportation of oneself or the goods produced to market, etc.). The specific combination of transaction costs will depend on the particular person or household (human capital, social capital, experience, accumulated information and information channels), on local specificities and on the specific market (Escobal, 2000). The different types of "distance" play a crucial role in this.

\section{The RNFE income and activity gradient}

Returning to the more economic view of "distance" (i.e., that of transaction costs generated by physical distance), evidence as to RNFE is still scant, but there is no doubt that distance and the transaction costs that ensue play a role both directly and indirectly, either through the non-separability of production/ consumption goods at the household level, or because if RNFE has at least partial linkages to agriculture and to the consumption of goods and services by agricultural households, then the effect of "distance" on agriculture and its products should also have an effect on RNFE.

Reardon, Berdegué and Escobar (2001) conclude that the share of income from wage employment in non-agricultural rural activities and from services tends to increase when transiting from the rural hinterland to rural areas close to towns and well served by roads. They explain this as empirical evidence that small rural manufacturing firms have difficulty competing with urban or imported manufactures and only tend to survive in isolated areas. This was also one of Renkow's (1998) conclusions, namely that the construction of roads was a double-edged measure, improving mobility both ways with the risk of crowding out local manufactures and services. Reardon, Berdegué and Escobar (2001) continue their analysis by saying that these effects require further study, but that at first sight it seems likely that, as rural Latin America becomes better served by road infrastructure and thus better connected to national and international markets, RNFE will increasingly be of a wage employment and service kind.

Much of a piece with Wiggins and Proctor's (2001) description of different rural areas referred to above is the division of such areas into four categories by the Brazilian Geographical and Statistical Institute (IBGE). Although "exclusively rural" areas (dispersed population, less than two community services such as school, church or health centre, no commercial centre or factory) are home to $82 \%$ of the total rural working population, they only represent $59 \%$ of RNFE. This shows that RNFE is closely linked to commercial centres and the basic infrastructure that usually accompanies them. The data also suggest that manufacturing and allied activities are not specifically concentrated in more urbanized centres, unlike commercial activities, which do tend to be more common there. Location thus influences the likelihood of participating in RNFE, even after controlling for all other characteristics. In relation to those residing in rural exclusive areas, those residing in extensão urbana areas have an 11 percentage point greater probability of participating in RNFE. The other types of rural settlements (rural povoado and rural núcleo) are also associated with a 3.6 and 9.8 percentage point higher probability of RNFE, respectively (Ferreira and Lanjouw, 2001). The same authors conclude that it is highly probable that the economies of smaller towns are more closely related to the rural economy than to the economies of larger urban areas.

In relation to the greater dependence of smaller towns on the rural economy and vice versa, Wiggins (2003) states that the goods and services resulting from RNFE are, with few exceptions, made from local raw materials and sold locally. The supply chain therefore often consists of no more than two or three actors who generally live in the same locality, know each other well and negotiate directly, face-to-face.

Per capita monthly incomes diminish as one moves from urban to rural areas and, in the latter, from multiple-activity zones to more specialized agricultural ones, both for households depending solely on agriculture and for those depending on multiple 
activities. Per capita incomes also vary by region, so that in Brazil, for example, the highest are found in rural areas of the state of São Paolo and the lowest in the regions to the north-east and south-east of the country (Graziano de Silva and del Grossi, 2001).

De Janvry and Sadoulet (2002) ${ }^{24}$ analysed the determinants of employment growth in manufactures and services in rural and semi-urban municipalities (15,000 inhabitants or less) in Mexico. They found that proximity to urban centres of 250,000 or more inhabitants, the regional context and the quality of the connections between rural and urban areas accounted for $94 \%$ and $67 \%$ of this employment growth in rural and semi-urban municipalities, respectively.

In El Salvador, Honduras and Nicaragua, RNFE significantly varies with regions, with most being concentrated around the capital and other especially dynamic or densely populated zones. Thus, in the central zone of El Salvador (which includes the capital San Salvador), some $50 \%$ of the rural EAP is occupied in RNFE, while in the east the figure is only $23.2 \%$, although the range of RNFE activities is fairly similar across regions and RNFE remunerations do not seem to be significantly influenced by geographical location (Lanjouw, 2001). In Nicaragua, non-agricultural rural income tends to be concentrated in rural areas around the capital, Managua; in more educated households in densely populated rural zones of the Pacific region that are well served by roads and close to major towns, cities or ports; and in the upper income quartile of rural households. By contrast, areas in the interior are restricted to small-scale manufacturing, stagnant local markets and RNFE jobs with low returns to labour (Reardon, Berdegué and Escobar, 2001). In Honduras, non-agricultural wage employment is particularly important in the northern region, where industrial freetrade zones have been established in the neighbourhood of San Pedro Sula and near Puerto Cortez, creating employment for some 50,000 people, especially young women. Rural non-farm wage employment in smallscale industries or services is particularly important in rural villages. Self-employment is more common in the southern region, where distribution services are relatively satisfactory. It includes services, handicrafts, food processing and commerce, all activities that require a higher population density to be sustainable. People without land and the residents of rural hamlets tend to be those that participate most in RNFE. In turn,

${ }^{24}$ Cited in Schejtman and Berdegué (2003). farmers who reside in small rural hamlets tend to rely on production systems that are relatively inputintensive (Ruben and Van den Berg, 2001).

In Peru, most rural households still obtain the bulk of their income by working their own farms. Because the coastal zones are richer and have a denser road network and better access to markets and cities, the expectation was that wage employment would feature more strongly in total family labour allocation there. However, data indicate few differences in regional patterns of agricultural employment versus RNFE and waged versus self-employment. In fact, rural non-farm income from both waged work and self-employment was found to be more important in the poorer regions, most probably due to "push" factors. This contrasts with large interregional variations in per capita income, coinciding with large variations in agricultural wages (wages in the coastal region are higher). Wages reflect agricultural productivity differences between the coastal and highland regions due to climate and farm size. RNFE productivity differs much less, though (Escobal, 2001).

In Ecuador, too, the 1995 household survey broke down the data for rural areas, this time into three categories. By contrast with the situation in Brazil, Mexico and Central America, people in the urban periphery (and also in dispersed areas) in Ecuador are less likely to be working in RNFE than those who live in rural amanzanado areas (settlements with some basic infrastructure but less than 5,000 inhabitants), and this holds true for both higher- and low-productivity occupations. Elbers and Lanjouw (2001) state that this is not particularly surprising in the case of dispersed areas, since households there are more likely to be employed in agriculture. However, the relatively low occurrence of RNFE in the urban periphery is disconcerting in view of the opportunities for non-farm employment in urban centres. There is also more poverty in the periphery than in the amanzanado areas or urban areas. The authors surmise that, in Ecuador, peri-urban areas function as temporary settlements for rural dwellers desirous of settling in urban areas. As such, few would be ready to make the investments needed for RNFE of any scope. A second reason is that the proximity to large urban markets induces intensive agriculture. Yet another reason, not explored by the authors, is that many recent migrants to peri-urban areas work as temporary agricultural wage labour. Hataya (1992), for example, explained that in Manizales, Colombia, most first-generation adult migrants did not qualify for any but menial, informal 
jobs, owing to lack of education and documentation (birth certificate, military status certification, etc.). As a consequence, they could earn more in temporary agricultural jobs (mainly coffee-picking). Their children, however, worked during their school vacations as agricultural wage labour, which had low barriers to entry, but looked forward to finding formal urban jobs upon finishing school.

By contrast with the situation in neighbouring Peru, in Ecuador people living in the coastal region are more likely to be working in RNFE than those in the highlands. This difference is not significant for higherproductivity RNFE, however, meaning that the coast has a higher proportion of low-productivity RNFE. This is consistent with a World Bank (1995) finding that in the coastal region of Ecuador poor people are mostly engaged in agricultural and non-agricultural wage employment while in the highlands the poor are more likely to be subsistence farmers. In the east, the probability of RNFE is lower than in the highlands, especially for low-productivity occupations (Elbers and Lanjouw, 2001).
In their analysis of RNFE in Chile, Berdegué, Ramírez and others (2001) were the first, to our knowledge, to look at where rural dwellers actually worked. They found that, both in an agriculturally dynamic area and in an agriculturally depressed area, around half of all those active in RNFE actually travelled daily to a nearby small town. This is a very important finding to which much more attention should be paid in future empirical studies because, if it transpires that it is not restricted to the particular circumstances of these two municipalities in Chile, or to some special characteristics of Chile, but is widely valid for most Latin American countries - and possibly also for other continents - then it will have a sobering effect on the enthusiasm that has arisen for RNFE as a rural "revival strategy". The foregoing illustrations show that, with very few exceptions, RNFE is more common and of a more dynamic type near more densely populated areas, or areas that are well connected to towns. This sheds new light on RNFE and the policies required to foster it, as well as their chances of success.

\section{VII}

\section{Conclusions and issues for further research}

Rural non-farm employment (RNFE) has received increasing attention in Latin America since the 1990s, and some $30 \%$ to $40 \%$ of economically active rural dwellers are engaged in RNFE while more than $40 \%$ of rural income stems from non-farm sources. Nonetheless, policy makers still essentially gear their rural development policies and actions toward the agricultural sector. This bias should be removed and rural development efforts should foster production and service linkages between "growth engines" -agricultural or not - and the local economy, considering the latter not only as the rural areas per se, but including the "natural" territory within which the local area is embedded and of which local residents feel they are a part, encompassing also the area in which most rural-urban linkages occur. And, as Reardon, Berdegué and Escobar (2001) put it, the challenge consists in mobilizing extra investment funds and capacities, public and private, as RNFE should not be promoted with resources diverted from agricultural development activities.
Most Latin American countries put decentralization policies in place in the 1990s, and almost all of them boosted rural infrastructure. The influence of these measures on migration patterns, whether of incoming public servants or private-sector workers or of rural people seeking new jobs, has not been studied so far. Decentralization policies have also given local governments the opportunity to control or participate in decisions concerning land-use planning, education, training, public infrastructure, etc., including the levying of taxes and the granting of permits that also tend to constitute high entry barriers for RNFE. They should make use of such opportunities to the utmost. Rural development projects financed by multilateral or bilateral donors are often the principal manifestation of public policies, especially in the poorer countries or regions. A fruitful dialogue is therefore needed in order to reach a common understanding as to priorities, complementarities and essential conditions. The possibility of building alliances with the private sector, i.e., with national and transnational conglomerates or 
even smaller firms ${ }^{25}$ that have a stake in the area or nearby, should also be explored. Of late, some large firms in the region have been showing increasing concern about their impact on the physical environment, and about their image. A few are also taking a more social approach. This should definitely be encouraged and taken advantage of by the national and local authorities as well as civil society.

Figures clearly show that some population groups are better represented in RNFE than others, namely: women (relative to their participation in the rural EAP), the more educated, and younger people (40 or so being the peak age for men and 30 or so for women). More analysis is needed to ascertain why this is so. It may be partly due to correlation, as younger people tend to have several more years of formal education than the previous generation; or to lack of access to land owing to the relative immobility of land markets, and customs and laws that lead to late inheritance; or to the widening of horizons and weakening of peasant traditions, so that younger people have more freedom of choice than their parents.

Asset endowment — both public and privatealso clearly plays a role in RNFE. Although the evidence does not always point clearly in one direction, in most instances a U-curve is found between RNFE income as a proportion of total income, and asset endowment (including land, number and education of household members, savings, etc.). Most of those with little access to assets who are in RNFE find themselves working in low-productivity jobs, being motivated more by "push" factors than by "demand" factors, whether they are in self-employment, wage employment or (although this was not mentioned in any of the studies we reviewed) unremunerated employment. Because of the characteristics of the left-hand side of the U-curve (both personal or household assets and activity type and remuneration), policy makers face great challenges in promoting rural non-agricultural employment and income for the alleviation of rural poverty. They should however be alert to the role that low-productivity RNFE has as a safety net for the poor and refrain from taking measures that could undermine this. It should be noted

\footnotetext{
25 The Fundación para la Superación de la Pobreza in Chile has recently started a project that involves identifying successful entrepreneurs to advise microentrepreneurs on their plans, in regular one-to-one discussion meetings, for a year. Willingness to do so has been unexpectedly high, especially among entrepreneurs from the same locality who themselves started out with small businesses a few decades ago.
}

too that the ultimate poverty refuge activity seems to be agricultural wage labour.

Indeed, all the evidence on Latin America shows that access to RNFE reduces poverty in two different, but equally important ways. Firstly, higher-productivity activities seem to provide sufficient income for households with limited access to land to avoid poverty. Secondly, the most vulnerable population segments, such as women, minorities and many of those who live in extreme poverty, tend to be concentrated in less productive RNFE. Nonetheless, these occupations provide crucial extra income, preventing more severe want.

Differentiated treatment must be given to richer and poorer rural areas. In the former, it is important to reduce the transaction costs faced both by agents investing in the engines of RNFE and by rural households seeking to participate in such employment. An active role on the part of the public sector is required to create conditions that increase the attractiveness of these regions for the private sector (roads, electrification, telecommunications, irrigation), as is a strong focus on public investment to develop the capacities of rural households so that they can participate in a broader range of activities (through education, access to credit, activation of land markets, etc.). In the case of poor areas whose relation to dynamic markets is weak or non-existent, it is essential to be prudent and avoid promoting microenterprises that end up providing "refuge RNFE" because they are unable to link up with dynamic markets where there is demand for the goods and services they produce (Reardon, Berdegué and Escobar, 2001). The point made in the previous paragraph should also be kept in mind.

Most RNFE studies point to the importance of infrastructure in rural development. It seems, however, that it is better to have a basic package combining simple - even rudimentary - services in communications, transport, energy and water than to have one or even a few of these services provided at a more sophisticated level. A concerted public (or private) investment effort directed at a given territory would thus bear much more fruit than isolated efforts. Other studies have shown that this should go together with access to credit and technology (or technical assistance). Yet other studies indicate that all these efforts should be directed at the population group that shows the requisite openness to change (often below a certain age group and above a certain educational level). Unfortunately, such concerted efforts directed at specific population 
subgroups are often difficult (not to say impossible) to decide upon and then co-ordinate among different public institutions used to working sectorally and independently. Such focused efforts also go against the interests of local politicians (and often national ones too) who require as broad a constituency as possible to be re-elected. The timing of policies and projects is also a difficulty here, as not all have the required visibility or bear fruit at the required political time. The trade-offs between impact and Realpolitik are harsh. For development and poverty reduction, efforts should lean towards impact.

Although rural development specialists are starting to look at territories and their heterogeneity in their analyses and when formulating development policies, and economists are slowly starting to see location as an explanatory factor in growth, the clustering of economic activities, etc., somehow location within rural areas and the "distances" (in relation to markets, information and organizations, as well as to concepts, logic and values) that go with it have not received sufficient attention so far. These issues are especially relevant in a continent where rural population densities tend to be low and rural infrastructure and services do not cover basic needs, either human or productive. Most of the studies on RNFE in Latin America reviewed in this article seem to show close associations between location and the type and dynamism of RNFE, but most of the authors fail to link this to their other findings or to identify location as - possibly - the central explanatory factor.

In the same vein, more attention should be given to the type of linkages that ensue from extensive versus intensive agriculture, from agro-processing and other activities, whether or not the latter tie in with agriculture, and from the economic agents engaged in each (from microenterprises to multinationals) in relation to location and "distances" (from physical to social) and local RNFE creation as well as the occurrence of "leakages" to the "rest of the world". There is definitely scope for policy options aimed at fostering more locally oriented linkages and therefore more RNFE as well.

Lastly, it is absolutely indispensable to look more closely at rural residents' daily journeys to work in urban areas (and vice-versa), rural-to-rural migration patterns and their relationship with access to public infrastructure and services, and RNFE. The results of this analysis will probably modify quite substantially the understanding we now have of RNFE, and this in turn will have its consequences for policy.
Andersen, J. (2003): Redes interorganizacionales e intervenciones en la salud, paper presented at the Seminar "Social capital, a tool for urban and rural poverty reduction programmes", (Santiago, Chile, ECLAC, 8 and 9 January 2003), Pontificia Universidad Católica del Perú.

Berdegué, J., E. Ramírez and others (2001): Rural nonfarm employment and incomes in Chile, World Development, vol. 29, No. 3, special edition, Amsterdam, Elsevier Science.

Corral, L. and T. Reardon (2001): Rural nonfarm incomes in Nicaragua, World Development, vol. 29, No. 3, special edition, Amsterdam, Elsevier Science.

De Janvry, A. and E. Sadoulet (1993): Rural Development in Latin America: relinking poverty reduction to growth, in M. Lipton and J. Van der Gaag, Including the Poor, Washington, D.C., World Bank.

(2001): Income strategies among rural households in Mexico: the role of off-farm activities, World Development, vol. 29, No. 3, special edition, Amsterdam, Elsevier Science. (2002): World poverty and the role of agricultural technology: direct and indirect effects, Journal of Development Studies, vol. 38, No. 4, April, London, Frank Cass \& Co.

Deininger, K. and P. Olinto (2001): Rural nonfarm employment and income diversification in Colombia, World Development, vol. 29, No. 3, special edition, Amsterdam, Elsevier Science.

Dirven, M. (2000): Empleo rural, grupos etarios y género, document presented at the Seminar "Ocupações rurais não-agrícolas" (Londrina, Brazil, 16-20 October 2000), Londrina, Paraná, Parana Institute of Agronomy (IAPAR).
(2001): Dairy clusters in Latin America in the context of globalization, International Food and Agribusiness Management Review, vol. 2, No. 3-4, Amsterdam, Elsevier Science.

(2002): Las prácticas de herencia de tierras agrícolas: ¿una razón más para el éxodo de la juventud?, Desarrollo productivo series, No. 135, LC/L.1837-P, Santiago, Chile, ECLAC, December. United Nations publication, Sales No. S.02.II.G.143.

ECLAC (Economic Commission for Latin America and the Caribbean) (2001): Social Panorama of Latin America, 1999-2000, LC/ G.2068-P, Santiago, Chile. United Nations publication, Sales No. E.00.II.G.18.

(2002): Social Panorama of Latin America, 2001-2002, LC/G.2183-P, Santiago, Chile. United Nations publication, Sales No. E.02.II.G.65.

ECLAC/CELADE (Economic Commission for Latin America and the Caribbean /Population Division-Latin American and Caribbean Demographic Centre) (1999): Latin America: Economically active population 1980-2025, Demographic Bulletin, No. 64, LC/G.2059, Santiago, Chile.

Elbers, C. and P. Lanjouw (2001): Intersectoral transfer, growth and inequity in rural Ecuador, World Development, vol. 29, No. 3, special edition, Amsterdam, Elsevier Science.

Escobal, J. (2000): Costos de transacción en la agricultura peruana: una primera aproximación a su medición e impacto, working document, No. 30, Lima, Grupo de Análisis para el Desarrollo (GRADE). 
(2001): The determinants of nonfarm income diversification in rural Peru, World Development, vol. 29, No. 3, special edition, Amsterdam, Elsevier Science.

Ferreira, F. and P. Lanjouw (2001): Rural nonfarm activities and poverty in the Brazilian Northeast, World Development, vol. 29, No. 3, special edition, Amsterdam, Elsevier Science.

Figueroa, A. (1986): Productividad y educación en la agricultura campesina de América Latina, Río de Janeiro, Program of Joint Studies of Latin American Economic Integration (ECIEL).

Graziano da Silva, J. and M.E. del Grossi (2001): Rural nonfarm employment and incomes in Brazil: patterns and evolution, World Development, vol. 29, No. 3, special edition, Amsterdam, Elsevier Science.

Hataya, N. (1992): Urban-rural linkage of the labour market in the coffee growing zone in Colombia, The Developing Economies, vol. 30, No. 1, March, Tokyo, Institute of Developing Economies.

IDB/FAO/ECLAC/RIMISP (Inter-American Development Bank / Food and Agriculture Organization of Economic Commission / The United Nations for Latin America and the Caribbean / Red Internacional de Metodología de Investigación de Sistemas de Producción) (2004): Empleo e ingresos rurales no agrícolas en América Latina, Seminarios y conferencias, Series No. 35, LC/2069-P, Santiago, Chile, ECLAC, April. United Nations Publication, Sales No. S.04.II.G.12.

Johnston, B. and P. Kilby (1975): Agriculture and Structural Transformation: Economic Strategies in Late Developing Countries, London, Oxford University Press.

Key, N., E. Sadoulet and A. de Janvry (2000): Transaction costs and agricultural household supply response, American Journal of Agricultural Economics, vol. 82, No. 2, May, Massachusetts, Blackwell Publishers.

Klein, E. (1992): El empleo rural no agrícola en América Latina, Documento de trabajo, No. 364, Santiago, Chile, Regional Employment Programme for Latin America and the Caribbean (PREALC).

Lanjouw, P. (2001): Nonfarm employment and poverty in rural El Salvador, World Development, vol. 29, No. 3, special edition, Amsterdam, Elsevier Science.

Löfgren, H. and S. Robinson (1999): To Trade or Not to Trade: Non-separable Farm Household Models in Partial and General Equilibrium, TMD Discussion Paper, No. 7, Washington, D.C., International Food Policy Research Institute (IFPRI), Washington, D.C.

Morales, C. (2003): Lo rural y lo urbano: un ejercicio de simulación sobre estos conceptos, Santiago, Chile, Economic Commission for Latin America and the Caribbean (ECLAC), unpublished.
Persson, L. and V.A. Ceccato (2001): Dora-Dynamics of rural areas. National report: Sweden, Nordregio, Nordic Centre for Spatial Development, October (electronic version).

Primi, A. (2002): The Costs of Distance: Rural Poverty Through a Territorial Perspective, thesis elaborated on the basis of the work performed at the Population Division-Latin American and Caribbean Demographic Centre (CELADE) (SeptemberDecember 2002), Pavia, Italy, University of Pavia.

Reardon, T., J. Berdegué and G. Escobar (2001): Rural nonfarm employment and incomes in Latin America: Overview and policy implications; World Development, vol. 29, No. 3, special edition, September, Amsterdam, Elsevier Science.

Renkow, M. (1998): Cities, Towns, and the Rural Non-farm Economy, document presented at the Workshop of the International Food Policy Research Institute (IFPRI) "Strategies for stimulating growth of the rural non-farm economy in developing countries" (Washington, D.C., 17-20 May 1998).

Ruben, R. and M. Van den Berg (2001): Nonfarm employment and poverty alleviation of rural farm households in Honduras, World Development, vol. 29, No. 3, special edition, Amsterdam, Elsevier Science.

Schejtman, A. and J. Berdegué (2003): Desarrollo territorial rural, draft paper presented at the Inter Agency Group for Rural Development Workshop (Milan, 21 March 2003).

Schultz, T. (1964): Transforming Traditional Agriculture, New Haven, Yale University Press.

UNCHS (United Nations Centre for Human Settlements) (1996): An Urbanizing World: Global Report on Human Settlements, 1996, HS/382/95/E, Oxford, Oxford University Press.

Wiggins, S. (2003): Can the Rural Non-farm Economy Beat Poverty in the Developing World? An Overview, document presented at the Symposium "The rural non-farm economy in the developing world and transition economies: an answer to rural poverty?", 77th Annual Conference of the Agricultural Economics Society (AES) (Seale-Hayne, Newton Abbott, Devon, 11-14 April 2003).

Wiggins, S. and S. Proctor (2001): How special are rural areas? The economic implications of location for rural development, Development Policy Review, vol. 19, No. 4, London, Overseas Development Institute.

Wordl Bank (1995): Ecuador Poverty Report, Report No. 14533EC. Washington, D.C.

Yúnez-Naude, A. and J.E. Taylor (2001): The determinants of nonfarm activities and incomes of rural households in Mexico, with emphasis on education, World Development, vol. 29, No. 3, special edition, Amsterdam, Elsevier Science. 